\title{
Digital Game-Based Learning as A Solution to Fun Learning Challenges During the Covid-19 Pandemic
}

\author{
Ika Febriana Wati ${ }^{1, *}$, Yuniawatika ${ }^{1}$ \\ ${ }^{1}$ Department of Elementary and Preschool Education, Faculty of Education, Universitas Negeri Malang, Malang, \\ Indonesia \\ ${ }^{*}$ Corresponding author. Email: ika.febriana.1601516@students.um.ac.id
}

\begin{abstract}
Education in Indonesia is one of the sectors that most affected by the Covid-19 outbreak. Finally, the Ministry of Education and Culture issued a policy for learning activities carried out from home. This new policy makes all elements of education must immediately adapt to existing conditions. Although learning is carried out online, it must still be following educational standards. The choice of learning model must be under the child's psychology to be fun learning. This article aims to review how the application of digital game-based learning can be a solution to fun learning challenges during the Covid-19 pandemic. The review focus on strategic ways to apply digital game-based learning to online learning in elementary schools. This study uses a descriptive content analysis method or a descriptive content analysis study. This method is a type of non-field research method. Based on the result, solutions that can be applied to online learning during the Covid-19 pandemic is digital game-based learning models. Some of the applications used in digital game-based learning activities are Kahoot, quizzes, and adobe flash. Digital game-based learning can foster learning motivation and student activity to be involved in learning. Besides that, the application of game-based learning is also able to improve student learning outcomes and creativity.
\end{abstract}

Keywords: digital game-based learning, fun learning, covid-19 pandemic

\section{INTRODUCTION}

The world is faced with nightmares in the health sector throughout 2020. The emergence of an outbreak of the pneumonia-like disease in Wuhan, China at the end of 2019 has made the world of health around the world chaotic [1]. This viral disease was later dubbed the Corona Virus Disease (Covid-19) [2]. This rapid spread across the globe has caused the World Health Organization (WHO) to set the status of Covid-19 as a global pandemic on March 11, 2020 [3], [4].

The conditions in Indonesia at the beginning of the pandemic were still very safe compared to neighboring countries in Southeast Asia. Even with the fourth largest population in the world, Indonesia is still 0 positive patients with the virus. Until finally, Covid-19 managed to penetrate Indonesia's defense for the first time in March 2020.

Lack of preparation at the start of the pandemic attacking the world caused Indonesia to be quite frantic to stem the spread of Covid-19. The increasingly emergency forced President Joko Widodo to declare Covid-19 a national disaster through Presidential Decree No. 12 of 2020 [5].
All development sectors in Indonesia were severely affected by the spread of Covid-19. Many sectors are aggressively declaring several policies as an effort to prevent the spread of the virus from this deadly disease. The systems that are most widely felt by society are the existence of social distancing policies and carrying out all activities from home. One sector that is in uproar in echoing policy is education [6]. The existence of a social distancing policy and having to carry out all activities from home urged the government through the Ministry of Education and Culture to schedule all learning activities to be done from home [7].

This new policy makes all elements of education must immediately adapt to existing conditions. There are no face-to-face activities or home visits until the end of the even semester of the 2019/2020 school year. All learning is transferred online or in a network (online). Online or online learning is learning with a knowledge transfer system through video, audio, images, text communication, software using internet network support [8]. The main characteristic of online learning is the integration and various technological innovations [9].

The implementation of online learning is not something new in the world of education [10]. The 
government hopes to provide new experiences in learning during the implementation of online learning [11]. But the implementation, which is quite sudden and continuous, has resulted in many complaints from various elements of education, especially teachers, students, and even student guardians. Regardless of the form of learning, the teacher still has to be able to adapt to various conditions of life in society [12]. Teachers are still required to design innovative, creative, and fun learning, even though the conditions are minimal.

In this challenging time, the challenges of becoming a teacher are increasing. This is because teachers are still required to design innovative, creative, and fun learning, even though the conditions are very limited. It is not enough to adapt to the use of new technology; teachers must also be able to manage it. Students who were initially motivated by a reward and punishment system now have to choose a variation of their learner model.

Students become a priority for consideration of how all elements of education must be able to design learning forms. The shocking pandemic condition made students experience a lot of anxiety in learning. This anxiety occurs because students have to learn and get enough assignments without direct teacher assistance. Thus, students will very quickly experience difficulties in learning. Besides, students are very prone to experiencing boredom when they have to study independently. This is because, during the implementation of the 2013 curriculum, one of the emphasis on the learning model is collaborative. So that most students are familiar with group learning activities with their friends.

Based on Regulation of Ministry of Education and Culture (Permendikbud) Number 22 of 2016 concerning Basic and Secondary Education Process Standards, the learning process should take place in an interactive, inspirational, fun, challenging, efficient, and motivate students to take an active role [13]. Learning that is carried out online must also keep pace with these rules. The key to the success of online learning is how to make learning fun, and students can stay entertained while learning.

Children can grasp the meaning of a lesson quite quickly when it comes to an interesting experience. They like to play some game that brought so much fun while they learn something [14]. Learning and playing in a fun atmosphere is a significant factor in education [15]. In a fun learning context, students must be actively involved in learning and have high learning motivation [16]. Fun learning creates a pattern of good relationships between students and teachers. There is no element of pressure or feeling of compulsion experienced by students or teachers [17].

The challenges of online learning can not only put pressure on students, but teachers are also greatly affected by this kind of learning. Teachers can go awry when required to provide fun learning but should not give too burdensome tasks. The teacher must find the right learning model to overcome this problem.

A learning model that can adapt to conditions during a pandemic and also creates such a fun learning condition is digital game-based learning. This model is a model adapted from game-based learning but with some adjustments. Game-based learning is the use of games to support the course of learning [18], [19]. Meanwhile, digital game-based learning or mobile game-based learning is one type of game that is specially designed where the operation uses digital equipment [20], [21].

The digital game-based learning model does not require face-to-face meetings. This model can also be applied to elementary school children, although they have to go through a process of adapting to the use of technology. Teachers can use this learning model as a material conveyor and student ability assessor. Educational games used are very diverse and can be created. With a right arrangement, the teacher indirectly gives assignments to children, but the packaging is fun for children.

Under the challenges of learning during the Covid-19 pandemic, which must be fun, digital game-based learning has the potential to be a suitable learning model solution to be applied. In this regard, this article aims to review how the application of digital game-based learning can be a solution to fun learning challenges during the Covid-19 pandemic. The review focus on strategic ways to apply digital game-based learning to online learning in elementary schools.

\section{METHODS}

This study uses a descriptive content analysis method or a descriptive content analysis study. This method is a type of non-field research method. The research was carried out by exploring various sources of literature to be used as a theory study, methodology, as well as a research study material. This type of text study has the advantage of a wide range of interpretations and authenticity [22].

The stage of this research refers to the modified descriptive method of content analysis [23]. Data is presented using informal presentation methods. The informal presentation method is a method of presenting data in the form of formulations with familiar words/phrases following linguistic rules. In presenting the data, the authors include quotes from various references used, in the way of analysis results, mentioning sources, and illustrated based on a summary or essence of information for each topic analyzed. This is done in the context of critical thinking and in-depth analysis of data [22].

The analysis was carried out on various articles regarding the application of digital game-based learning, 
especially during the Covid-19 pandemic. The scientific articles used for the study were obtained from various international and national journals, as well as other relevant sources.

\section{RESULTS AND DISCUSSION}

The Covid-19 outbreak has devastated the education sector in Indonesia. The study from home policy is also the most appropriate option to continue the steps of Indonesian education in achieving national education goals [7]. Teachers and students must continue to collaborate well to keep creating optimal online learning.

The implementation of online learning during the Covid-19 pandemic is a challenge for teachers and students. Learning that must change suddenly makes all elements of education have to go the extra mile to meet the learning objectives still to be achieved. To continue to create a learning atmosphere under the rules set by the Ministry of Education and Culture, teachers must make learning variations more enjoyable and fun.

\section{a. The Concept of Fun Learning during the Covid- 19 Pandemic}

At first, the spread of Covid-19 had a major impact on the economic world which was starting to decline, but now the impact is also being felt by the world of education. The policy for restricting movement outside the home and meeting with others makes the government and related institutions have to present an alternative educational process for students who cannot carry out the educational process at educational institutions.

The final decision regarding the learning process during the Covid-19 pandemic is that learning is carried out online. The direction of learning, according to the Ministry of Education and Culture, is contained in Circular No. 4 of 2020, Regarding the Implementation of Education Policies in an Emergency for the Spread of Corona Virus Disease (Covid-19). Some important points from this circular regarding the implementation of learning during the Covid-19 pandemic include: (1) learning from home through online/distance learning to provide meaningful learning experiences for students without being burdened with demands to complete all curriculum achievements for class advancement and graduation; (2) learning from home can be focused on life skills education, among others regarding the Covid-19 pandemic; (3) Learning activities and assignments from home can vary among students, including considering gaps in access to learning from home; and (4) evidence or products of learning activities from home are given qualitative and useful feedback from the teacher, without being required to provide quantitative scores [7].

The decision to implement an online learning policy in Indonesia is a policy that is quite appropriate compared to having to stop learning activities completely. If the education sector is completely closed, there will certainly be an education crisis. Do not rule out the possibility that the crisis in the education sector will continue even though the pandemic has ended. This is because it takes too long for students to stop learning so that when school starts again, students will have difficulty reconstructing their knowledge also. If something like this happens, it is inevitable to repeat the material from the beginning of the semester to reconstruct a complete perception of learning material. Other impact learning will be choked up for one to two semesters. Therefore, even though it is still halting and needs high adaptation, the decision to continue learning online is the wisest decision by the government in the field of education.

Almost all countries in various parts of the world have also adopted the policy of continuing to implement online learning [24]. One example is in the superpower, the United States. In the United States, a study guide entitled "Pandemic Preparedness" has been published. This guide focuses on forms of learning that are transferable online. According to the Arizona Department of Education in early March 2020, the sub-section "Continuity of Education Instruction" has emphasized that it is important to continue to carry out learning so that students' thinking construction does not pause and continue to develop. This decision is expected to be a solution so that the post-pandemic crisis in various fields in the future can be resolved, especially in the field of education. In addition to using various existing documents, learning should be transferred to technologybased. In other words, this guide proposes education in America to be implemented online [25].

Online learning has truly been known in Indonesia for a long time. Nevertheless, due to limited facilities and more effective face-to-face learning, the implementation is still unfamiliar to most people in Indonesia. In China, there has been researched on online learning activities, which the main study is called the Smart Learning Environment. One of the primary outcomes of this research is that all types of technological equipment developments need to be optimally utilized. This is because technological developments can provide comprehensive support for student intelligence [26].

The fundamental difference between face-to-face learning and online learning is the use of information and communication technology and the form of interaction between students and teachers when learning takes place. These two types of learning both have their own advantages and disadvantages. The comparison of online learning and face-to-face learning is presented in the Table 1. Regarding the criteria for ongoing learning, either face-to-face or online, it must still be based on the same rules, namely based on Permendikbud Number 22 of 2016 concerning Basic and Secondary Education Process Standards. 
Table 1 The Comparison of Online and Face-To-Face Learning

\begin{tabular}{|c|l|l|l|}
\hline \multirow{2}{*}{ No } & \multirow{2}{*}{ Indicators } & \multicolumn{1}{|c|}{ Learning Style } \\
\cline { 3 - 4 } & $\begin{array}{l}\text { Role of } \\
\text { students }\end{array}$ & $\begin{array}{l}\text { Online } \\
\text { Troubleshooter, } \\
\text { explorer, more } \\
\text { active There is a } \\
\text { distance, }\end{array}$ & $\begin{array}{l}\text { Listener, receiver, } \\
\text { more passive }\end{array}$ \\
\hline 2 & Interactions & $\begin{array}{l}\text { There is a distance, } \\
\text { closer between } \\
\text { parents and } \\
\text { students }\end{array}$ & $\begin{array}{l}\text { Flexible, closer } \\
\text { between teachers } \\
\text { and students }\end{array}$ \\
\hline 3 & Study time & Flexible & $\begin{array}{l}\text { Regular and less } \\
\text { flexible }\end{array}$ \\
\hline 4 & Role of teacher & Facilitator, monitor & $\begin{array}{l}\text { Manager, time } \\
\text { and materials } \\
\text { expert }\end{array}$ \\
\hline 5 & $\begin{array}{l}\text { Learning } \\
\text { environment }\end{array}$ & $\begin{array}{l}\text { At home, } \\
\text { independently, } \\
\text { more flexible, } \\
\text { required technology }\end{array}$ & $\begin{array}{l}\text { At school, } \\
\text { together, less } \\
\text { flexible, it just } \\
\text { takes technology } \\
\text { sometimes }\end{array}$ \\
\hline 6 & $\begin{array}{l}\text { Assignment } \\
\text { and } \\
\text { Accumulation }\end{array}$ & $\begin{array}{l}\text { Too many, but } \\
\text { more flexible }\end{array}$ & $\begin{array}{l}\text { A few, but less } \\
\text { flexible }\end{array}$ \\
\hline
\end{tabular}

In this rule, it is emphasized that the learning process should take place in an interactive, inspirational, fun, challenging, efficient, and motivate students to take an active role [27]. Based on these rules, one of the criteria for meeting the standards of the education process in elementary schools is that learning must take place in a fun way. Fun learning is a model in learning that supports the development of creative thinking and creates a pleasant learning atmosphere [16].

Fun learning will have a big positive impact on students. When students study in a fun atmosphere, motivation to learn is high. With high learning motivation, learning outcomes can also increase. In addition, a pleasant learning atmosphere can foster student creativity. Students tend to find lots of new ideas and find many ways to solve problems in learning material. One more thing that is greatly influenced by a pleasant learning atmosphere is the activeness and involvement of students in learning. This is because students feel comfortable and are not burdened by a series of learning activities so that students actively ask, answer, or just respond to what they are learning.

About fun learning during the Covid-19 pandemic, several characteristics of fun learning must be found in online learning. These characteristics include an interactive relationship between teachers and students, students are actively involved in responding or solving a problem in learning, students have high learning motivation, and students and teachers feel not burdened by the course of learning activities [16], [17]. Not much different, other research shows that the characteristics of fun learning include: (1) creating an environment without stress, (2) the material provided is relevant to the level of children's development, (3) learning emotionally, such as humor and encouragement, (4) involving all senses and the left brain (analytical) and right (social), and (5) challenging learners and express what is being learned [28].

Comprehension strategies in creating fun learning are the initial majuscule that teacher's must-have for designing learning forms. The psychological condition of students is an initial consideration in choosing a way of learning. The definition of a fun learning strategy is a strategy used to design an effective learning environment, implement a curriculum, deliver material, and facilitate the learning process [29], [30]. Besides, a fun learning strategy can also be interpreted as a pattern of thought and direction of action taken by the teacher in selecting and implementing methods of delivering material so that it is easy for students to understand and allows a learning atmosphere to be achieved not tiresome for students [31].

About one of the characteristics of fun learning, the closeness between teachers and students, many studies have shown that academic achievement and student behavior are influenced by the quality of the teacherstudent relationship. Research conducted on low-grade students in America indicates that student-teacher relationships can influence student's feelings about autonomy, ability, and familiarity [32]. Other studies have shown that positive language behavior from teachers can influence student behavior in the learning process [33]. There are also research results suggesting that teachers who have good personal relationships with their students can improve children's learning achievement and socio-emotional abilities [34], [35]. The personal quality of the teacher can make students feel confident in doing any given learning task and make students feel more relaxed and comfortable in participating in learning [36], [37], [38].

\section{b. Implementation of Digital Game-Based Learning}

Children and play are inseparable. It is impossible to know that there are children who do not enjoy playing. Playing is an activity that is inherent in children from birth. Children will integrate play activities in every activity they do. It is not uncommon for us to find small things that show that playing has become an inherent activity for children. The real example is that we often see children who can't stay still while walking. There are their behaviors such as kicking rocks as if they were playing soccer, jumping here and there, playing with the leaves they passed, and so on. This clearly shows that playing has become a child's instinct.

Activities carried out by children in the form of learning always take the form of play, and this is because game is indeed the child's soul. Playing is an activity that is repeated and creates pleasure/satisfaction for oneself. Playing is also a means of socialization that can allow 
children to explore, discover, express feelings, be creative, and learn in a fun way [16].

Besides feeling happy, children also very easily appreciate the knowledge that comes from interesting experiences. They are happy with a game that is fun [16]. Learning and playing in a fun atmosphere is a crucial factor in education. The results of research in the Netherlands show that playing and having fun are essential activities for all humans [39]. In positive psychology, the theorists explain in flow theory that human beings can do anything in the best way if they can be involved in fun activities [40]. For this reason, designing fun learning strategies for elementary schoolage children in the form of games is a good alternative for teachers.

The play has distinctive features that differentiate it from other activities. Playing activities in children have the following characteristics: (1) game is always pleasurable, enjoyable or enjoyable; (2) play does not have an extrinsic purpose, motivation play is intrinsic to the child; (3) play is spontaneous and voluntary, not forced; (4) play involves the active role of all participants according to their respective roles and turns; and (5) play is flexible, children can freely choose and switch to activities play whatever they want. Sometimes children move from one play activity to another that is not too long [41].

Children's love for play can be an inspiration for teachers to design fun online learning models. The model that can be applied is digital game-based learning. Gamebased learning is the use of games to support learning [18], [29]. Meanwhile, digital game-based learning or mobile game-based learning is one type of game that is specially designed where the operation uses digital equipment [20], [21].

The application of digital game-based learning has its own difficulty level for students and teachers. Teachers must be willing to practice to be able to create a fun digital educational game for children. Meanwhile, students must practice operating the game. But on the bright side, students will remain enthusiastic about learning, and teachers do not need to have difficulties in providing learning motivation to students. Teachers can take advantage of educational games in every part of the learning activity. Games can be served as an opening for learning, delivering material, quizzes or assessment questions, or closing lessons.

The use of digital game-based learning is expected to be easily operated by elementary school children. The concerns of various parties regarding the difficulty of operating digital educational games for elementary school-age children have received fresh air from the habits seen in the children themselves today. This is because the number of children's interest in online games is quite high. Many elementary school-age children are addicted to online games. We can view this from a positive point of view, considering the features provided by online games are not much different from the educational games implemented by teachers.

It has been almost two decades since online games entered Indonesia; the number of enthusiasts is increasing rapidly. The development of online game addicts has spread to all age groups, including elementary school children [42], [43]. Research results from the Kaiser Family Foundation and the Children's Digital Media Centers found that children in the United States are growing up with media and are spending hours a day watching television and videos, using computers, and playing video games [44]. The penchant for elementary school-age children to be a gamer shows that elementaryage children can master technology. One of the factors that influence children to be able to master this kind of technology is the child's joy when playing, primarily digitally.

It cannot be denied that the very rapid development of online game technology also has many negative impacts on its users. At the age of elementary school children, online games provide a strong enough attraction to make them addicted. Besides, online games that are reckless are very prone to spread negative things that cannot be filtered out by elementary school children. Examples are elements that lead to pornography and violence. Concerning these problems, the selection of games played by children must be directed at positive things and can help make learning more enjoyable. This is the location of the advantages provided by educational games in digital game-based learning. Besides, children can satisfy their passion for playing and using technology, they also get useful knowledge materials.

Many studies support the effective use of educational games to be integrated into learning. In a study, it is stated that one of the positive effects of using games is fun and entertaining games and games that provide practice to solve problems and logic so that they are accustomed to actively thinking, learning, and practicing even at home [45]. Taking advantage of the gamification feature can add to the learning experience to be more exciting and enjoyable. Thus, the online gamification feature can increase student interest in learning and motivation in the learning process [46].

In Indonesia, the application of digital game-based learning uses a lot of educational games that are simple, easy to manufacture and operate, accessible for free, and can also be used for assessment. Some types of digital educational games that are widely used in learning are Kahoot, Quizizz, and Adobe flash [47], [48], [49].

Kahoot is a free and fun game-based learning platform for learning and the development of learning materials that can be customized by users (Figure 1). Kahoot is an online non-paid question-based learning 
media used in teaching and learning activities to evaluate the results of the student learning process, repeat the subject matter, and stimulate students' interest in having discussions both in groups and classically about the questions given by Kahoot [47].

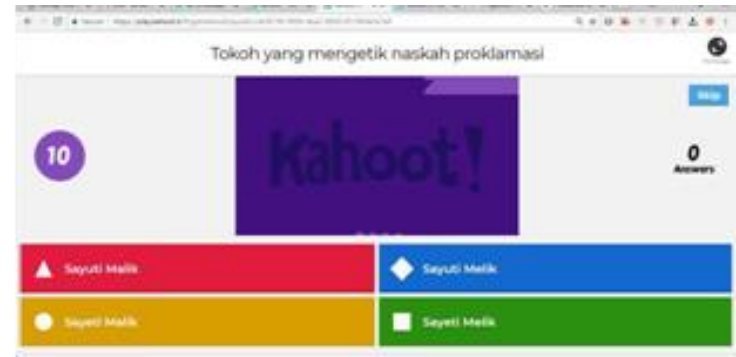

Figure 1 Quiz display on Kahoot Game

The quizzes educational game is a game app that contains multi-game activities and makes interactive exercises fun (Figure 2). The application of quizzes educational games can be carried out by students at home using their electronic devices such as smartphones and laptops. Quizizz educational games have character themes, memes, avatars, and music that can entertain students during the learning process, practice, or do quizzes independently [48].

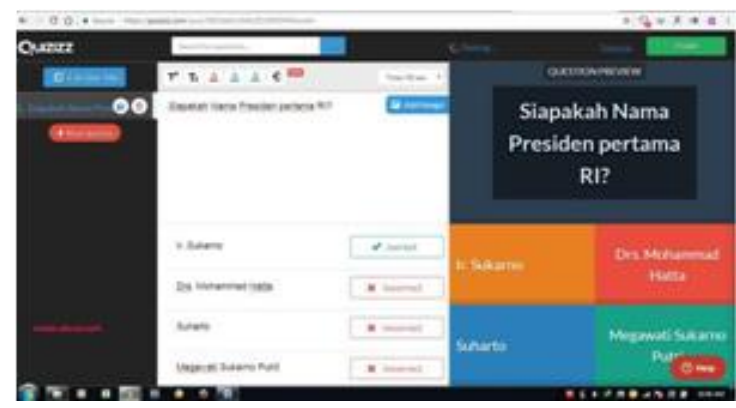

Figure 2 Quiz display on Quizizz game

Adobe flash is a graphic animation program that is widely used by designers to produce professional works, especially in the animation field (Figure 3). This application can be used to create interactive digital educational games. Many animations can be included in the game. The final form of the game is very diverse, some resembling interactive videos, interactive slides, and so on [49]

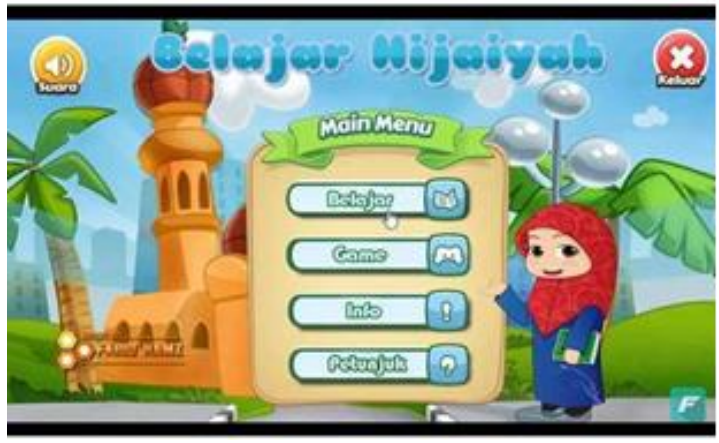

Figure 3 The example of Adobe Flash-based game
Apart from manufactured games, teachers can also easily take advantage of the educational games that are already available. Most digital games can be easily accessed via Android phones and are in the form of applications. In Google's application provider warehouse, namely Google Play, there are more than 700,000 game applications as a provider for various applications. However, most of these games are available in the form of games that are less educational. Some examples of android-based educational games that can be used in learning are Learn Alphabet (a game to recognize and arrange letters), Learn Math (a counting game) Puzzle (a game to compose pieces of pictures), Iqra '(a game about hijaiyah and reciting letters), and Cerita Rakyat Nusantara (a game about fairy tales about folk tales) (Figure 4).

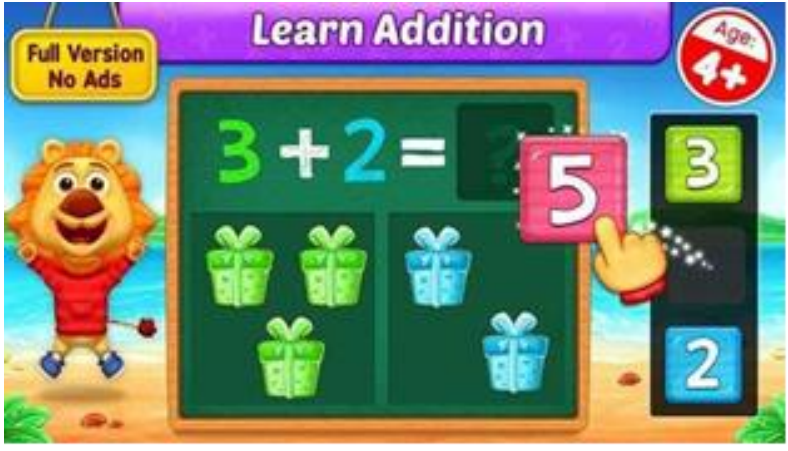

Figure 4 The example of Android based game

\section{c. Benefits of Implementing Game-Based Learning during the Covid-19 Pandemic}

The majority of the general public has the perception that play activities only have an impact on children's psychological pleasure. In fact, by doing an educational game, children will get many extraordinary things that are more than that. There are many positive impacts of playing digital educational games for elementary school children. One of them is learning that is delivered through games will be easier for children to remember so that the material is stored in long term memory. Furthermore, children are more honed in thinking, creativity, and problem-solving. Children who learn to use digital educational games are also indirectly honed their motor skills in operating a device.

Many studies agree with the various positive impacts of implementing digital educational games. According to one of the research results, there are 5 tangible benefits from playing activities, namely the benefits of: (1) motor, (2) effective, (3) cognitive, (4) spiritual, and (5) balance. Motor benefits are the benefits associated with the positive values of toys that occur in the physical way of the child. Usually, this is related to elements of health, skills, talent, and specific physical abilities. Affective benefits are the benefits of toys related to children's psychological development. The elements included in this group include instincts, feelings, emotions, 
traits/characters/dispositions, and one's personality. Cognitive benefits are the benefits of games for the development of children's intelligence. Usually, this is related to the ability of imagination, the formation of reason, logic, and systematic knowledge [16].

Digital game-based learning utilizes learning through learning and playing patterns using a computer or smartphone device. The use of media and the Digital Game Base Learning method is a very close combination with the daily activities of students today that we know as the millennial generation. This closeness will bring joy and increase the motivation of students. In Digital Game Base Learning, it is designed to include elements of competition and cooperation in solving cases in each stage of the problems being worked on [50].

Various studies have proven the benefits of gamebased learning or digital game-based learning. By implementing game-based learning, it can make students more excited and motivated to learn. With games, students are also more enthusiastic and active in learning [51], [52], [53].

Besides, several other studies have shown that applying digital game-based learning can improve student learning outcomes [54], [55]. Furthermore, digital game-based learning is also able to foster or increase student creativity [56], [57]. With the many research results regarding the benefits of digital gamebased learning, it is hoped that it can be an encouragement for teachers to continue working in developing fun learning models. Many parties can contribute to making this development a reality. The government can hold training for teachers to be able to create their digital educational games. This is solely for the development of education in Indonesia for the better

\section{CONCLUSION}

Covid-19 Pandemic is breaking out all over the world. Education in Indonesia is one of the sectors that most affected by the Covid-19 outbreak. As e result, learning cannot be carried out face to face. Finally, the Ministry of Education and Culture issued a policy for learning activities carried out from home. This new policy makes all elements of education must immediately adapt to existing conditions.

Although learning is carried out online, it must still be following educational standards. The choice of learning model must be under the child's psychology to be fun learning. Solutions that can be applied to online learning during the Covid-19 pandemic is to implement digital game-based learning models.

The implementation of digital game -based learning can be carried out in many ways. Some of the applications that most often implemented in digital gamebased learning activities in Indonesia are Kahoot, quizzes, and adobe flash. Digital game-based learning can foster learning motivation and student activity to be involved in learning. Besides that, the application of game-based learning is also able to improve student learning outcomes and creativity.

Following the results of various studies that prove the many benefits of implementing digital game-based learning, it shows that the application of the digital gamebased learning model can create fun learning. Students will be more active and enthusiastic in learning. With this activity, students will be fonder of responding, answering, and asking questions to the teacher. This will build closeness between teachers and students. The application of game-based learning has also proven to be classified as learning that does not cause pressure or stress on students or teachers. Students are happy to do the assignments given by the teacher without feeling overwhelmed.

Meanwhile, teachers also find it easier to evaluate students' abilities. As a result, student learning outcomes will be significantly affected. Student learning outcomes can be improved, and problem-solving skills are also increasingly pointed.

\section{REFERENCES}

[1] Lee, A. "Wuhan novel coronavirus (COVID-19): why global control is challenging?" Public Health, January, 2020, pp. 19-21.

[2] World Health Organization (WHO). "WHO DirectorGeneral's remarks at the media briefing on 2019-nCoV on 11 February 2020.”, January 11st, 2020. [Online] Retrieved from: https://www.who.int/dg/speeches/detail/ who-director-general-sremarks-at-the-media-briefingon-2019-ncov-on-11-february-2020. [Juli 20th, 2020].

[3] World Health Organization (WHO). "WHO DirectorGeneral's opening remarks at the media briefing on COVID-19 - 11 March 2020.”, March 11st, 2020. [Online]. Retrieved from: https://www.who.int/dg/speeches/detail/who-directorgeneral-sopening-remarks-at-the-media-briefing-oncovid-19---11-march-2020. [Juli 20th, 2020].

[4] Cucinotta, D., \& Vanelli, M. "WHO declares COVID-19 a pandemic", Acta Bio-Medica : Atenei Parmensis, no. 91, vol. 1, pp. 157-160, 2020. https://doi.org/10.23750/ abm.v91i1.9397

[5] Keppres No. 12 Tahun 2020 Tentang Penetapan Bencana Nonalam Penyebaran Corona Virus Disease 2019 (Covid19) Sebagai Bencana Nasional

[6] Azzi-Huck, K., \& Shmis, T. "Managing the impact of COVID-19 on education systems around the world: How countries are preparing, coping, and planning for recovery", World Bank Blogs, 2020.

[7] Kementerian Pendidikan dan Kebudayaan. "Surat Edaran No. 4 Tahun 2020, Tentang Pelaksanaan Kebijakan Pendidikan dalam Masa Darurat Penyebaran Corona Virus Disease (Covid-19)"

[8] Basilaia, G., \& Kvavadze, D. "Transition to Online Education in Schools during a SARS-CoV-2 Coronavirus (COVID-19) Pandemic in Georgia", Pedagogical Research, 5, no. 4, 2020. https://doi.org/10.29333/ $\mathrm{pr} / 7937$. 
[9] Banggur, M. D. V., Situmorang, R., \& Rusmono. "Pengembangan Pembelajaran Berbasis Blended Learning pada Mata Pelajaran Etimologi Multimedia", JTP - Jurnal Teknologi Pendidikan, 20, no. 2, pp.152165, 2018. https://doi.org/10.21009/JTP2002.5

[10] Trucano, M. "Education \& technology in an age of pandemics", EduTech, 2020.

[11] Fajar, T. "Arti belajar di rumah di tengah wabah virus corona" Okezone News, March 25th, 2020. [Online]. Retrieved from https://news.okezone.com/read/2020 /03/25/65/2188872/arti-belajar-di-rumah-di-tengahwabah-virus-corona. [August 14th, 2020].

[12] Zein, M. "Peran guru dalam pengembangan pembelajaran". Journal UIN-Alauddin, no. 5, vol. 2, pp. 274-285, 2020. https://doi.org/10.24252/ip.v5i2.3480

[13] Kementerian Pendidikan dan Kebudayaan. "Permendikbud No. 22 Tahun 2016 tentang Standar Proses Pendidikan Dasar dan Menengah"

[14] Samad, Farida, and Nurlela Tidore. "Strategi Pembelajaran Bahasa Inggris yang Menyenangkan untuk Anak Usia Dini." Cahaya PAUD, no. 2, vol. 1, pp. 47-57, 2016.

[15] Hamid, M. Sholeh. "Metode Edutainment", Jogjakarta: Diva Press, 2012.

[16] Trinova, Zulvia. "Hakikat Belajar dan Bermain Menyenangkan bagi Peserta Didik." Al-Ta Lim Journal, no. 1, vol. 3, pp. 209-215, 2012. http://journal.tarbiyahiainib.ac.id

[17] Rusman. "Model-model Pembelajaran Mengembangkan Profesionalisme Guru" Jakarta: Raja Grafindo Persada, 2010.

[18] Harriehausen-mühlbauer, B. "Quiz Lounge: game-based learning on mobile devices," J. Syst. Cybern. Inf 11 no. 6, pp 82-87, 2013.

[19] Perrotta, C., Featherstone, Aston, H., and Houghton. "Game-based learning: latest evidence and future directions" 1 no. 1. Berkshire: NFER, 2013.

[20] Sćepanović, S., Vujičić, T., Matijević, T., and Radunović, P. "Game based mobile learning - application development and evaluation," Sixth Int. Conf. eLearning, no. September, pp 24, 2015.

[21] Shiratuddin, N., and Zaibon, S. B. "Mobile game-based learning with local content and appealing characters," Int. J. Mob. Learn. Organ 4 no. 1, p 55, 2010.

[22] Ahmad, Jurnal. "Desain Penelitian Analisis Isi (Content Analysis)", Researche Gate, pp. 1-20, 2018

[23] Prasad, D. "Content Analysis A Method in Social Science Research", J. Research Method for Social Network 5, pp. 173-193, 2010.

[24] Wahyono, Poncojari, H. Husamah, \& Anton Setia Budi. "Guru profesional di masa pandemi COVID-19: Review implementasi, tantangan, dan solusi pembelajaran daring", Jurnal Pendidikan Profesi Guru, no. 1, vol. 1, pp. 51-65, 2020. http://ejournal.umm.ac.id/index.php/jppg

[25] Arizona Department of Education. "Pandemic preparedness (Issue March)", 2020.

[26] Huang, R., Yang, J., and Zheng, L. "The Componentsand Functions of Smart Learning Environments for Easy, Engaged and Effective Learning Ronghuai Huang TheDemands on Rebuilding Learning Environments in Infor-mation Society Predicaments of current learning environ-ments in formal educational", 2013.

[27] Permendikbud No. 22 Tahun 2016 tentang Standar Proses Pendidikan Dasar dan Menengah

[28] Jamal Ma'mur Asmani. "7 Tips Aplikasi PAKEM", Jogjakarta: Diva Press, 2011.
[29] DePorter, Bobbi. "Quantum teaching/learning", Bandung: Kaifa, 2000.

[30] Darmansyah. "Strategi pembelajaran menyenangkan dengan humor", Jakarta: Bumi Aksara, 2010.

[31] Berk, Laura E. "Development through the lifespan", Pearson: United Kingdom, 1998.

[32] Matusovich, Holly M, et. all. "How Instructors and Classroom Climate Contribute to the Motivation of FirstYear EngineeringStudents", 2011, [Online].

[33] Pasquet, Maud Budhoo. "When Positive Language Leads to Positive Classroom Changes: A Grounded Theory of Teachers' Experience of a Solution-Focused Approach to Classroom Management”, 2011,[Online], Retrieved from:

http://www.broward.k12.fl.us/research_evaluation/resear chresults/ 544/544FinalDissertation.pdf, [14th August 2020]

[34] Jones, Vern and Jones, Louise. "Manajemen Kelas Komprehensif edisi kesembilan", Translated by Irawati, Jakarta: Kencana, 2012

[35] Hamre, Bridget K and Robert C. Pianta. "StudentTeacherRelationship", 2006, [Online], Retrieved from:http://www.pearweb.org/conferences/sixth/pdfs/N AS-CBIII-05-1001-005-hamre\%20\&\%20Pianta\%20 proof.pdf, [14th August 2020]

[36] Ryan, Allison M and Helen Patrick. "The Classroom Social Environment and Changes in Adolescents' Motivation and Engagement During Middle School", American Educational Research Journal Summer, no. 38, vol. 2, pp. 437-460, 2001,[Online], Retrieved from: http://www.sagepub.com/scarlettstudy/articles/Ryan.pdf, [14th August 2020]

[37] Darmansyah. "Strategi Pembelajaran Menyenangkan Dengan Humor", Jakarta: Bumi Aksara, 2010.

[38] Iriantara, Yosal. "Komunikasi Pembelajaran Interaksi, Komunikatif dan Edukatif dalam Kelas”, Bandung: PT Remaja Rosda Karya, 2014

[39] Huizinga, Johan. "Homo Ludens: A Study of the Playelement in Culture. Front Cover", Beacon Press, 1955.

[40] Csikszentmihalyi, Mihaly. "Finding Flow: The Psychology of Engagement With Everyday Life", Basic Books, 1998.

[41] Musfiroh, Tadkiroatun. "Bermain sambil Belajar dan Mengasah Kecerdasan”, Jakarta: Depdiknas, 2005.

[42] Hanum, Khikmiyah. "Aktivitas Game Online Siswa SD (Kelas 3-6) (Studi Deskriptif Di Warnet Kelurahan Gunung Anyar Kota Surabaya)" AntroUnair, vol. 4, no.2 pp. 137-146, Juli 2015.

[43] Wardayani, Gisma Dian., Rohmatun, and Fitriani, Anisa. "Hubungan Antara Pola Asuh Autoritatif Orang Tua dan Kontrol Diri Dengan Kecenderungan Kecanduan Game Online Pada Remaja Di SMPN 4 Semarang”, Prosiding Konferensi Ilmiah Mahasiswa UNISSULA (KIMU) 2 Universitas Islam Sultan Agung Semarang, October 2019.

[44] Rideout, V. J., Vandewater, E. A., \& Wartella, E. A. "Zero to six: Electronic media in the lives of infants, toddlers and preschoolers",2003. [Online]. Retrievedfrom:http://www.kff.org/entmedia/3378.cfm. [August 22, 2020]

[45] Henry, S. "Cerdas dengan Game", Jakarta: PT Gramedia Pustaka Utama, 2010

[46] Nugroho, Dwi Yulianto., Situmorang, Komilie., Tahulending, Peggy Sara., Maxmilla, Maria., and Rumerung, Christie Lidya. "Pemanfaatan Teknologi Dalam Pendidikan: Penggunaan Fitur Gamifikasi Daring 
Di YPK Penabur Bandar Lampung”, Prosiding PKMCSR, vol. 2, pp. 1-9, 2019.

[47] Hartanti, Dwi. "Meningkatkan Motivasi Belajar Siswa dengan Media Pembelajaran Interaktif Game Kahoot Berbasis Hypermedia." Prosiding Seminar Nasional PEP 2019, vol. 1, no. 1, 2019.

[48] Rusmana, Indra Martha. "Pembelajaran Matematika Menyenangkan dengan Aplikasi Kuis Online Quizizz." Prosiding Sesiomadika, vol. 2, no. 1a, 2020.

[49] Hanafri, Muhammad Iqbal, Agus Budiman, and Nugroho Arif Akbar. "Game Edukasi Tebak Gambar Bahasa Jawa Menggunakan Adobe Flash CS6 Berbasis Android." Jurnal Sisfotek Global, vol. 5, no. 2, 2015.

[50] Putri, Aprilia Riyana and Muzakki, Muhammad Alie. "Implemetasi Kahoot Sebagai Media Pembelajaran Berbasis Digital Game Based Learning dalam Mengahadapi Era Revolusi Industri 4.0", Prosiding Seminar Nasional "Penguatan Muatan Lokal Bahasa Daerah sebagai Pondasi Pendidikan Karakter Generasi Milenial”, 2019.

[51] Tomic and Divjak. "The Impact of Game-Based Learning on the Achievement of Learning Goals and Motivation foR Learning Mathematics -Literature Review," J. Inf.Organ. Sci 35 no. 1, pp 15-30, 2011.

[52] Kurkovsky. "Mobile game development: Improving student engagement and motivation in introductory computing courses," J. Comput. Sci. Educ., vol. 23, no. 2, p. 138-157, 2013.
[53] K Fahuzan and R H Santosa. "Gender Differences in Motivation to Learn Math Using Role Play Game in Smartphone" Journal of Physics: Conference Series. IOP Conf. Series: Journal of Physics: Conf. Series 1097012130 , pp. 1-7, 2018. doi :10.1088/1742$6596 / 1097 / 1 / 012130$

[54] Noviyanti, Gladis Vella. "Pengaruh Game Based Learning Terhadap Hasil Belajar Mata Pelajaran Ekonomi Kelas X SMA”, JUPE, Vol. 6 No. 2, pp. 110115, 2018.

[55] Wulandari, Susilo, and Kuswandi. "Penggunaan Multimedia Interaktif Bermuatan Game Edukasi Untuk Meningkatkan Aktivitas dan Hasil Belajar Siswa Sekolah Dasar". Jurnal Pendidikan: Teori,Penelitian, dan Pengembangan, Vol. 2 No. 8, pp: 1024-1029, 2017.http://journal.um.ac.id/index.php/jptpp/

[56] Hsiao, H. S., Chang, C. S., Lin, C. Y., \& Hu, P. M. “ Development of children's creativity and manual skills within digital game-based learning environment". Journal of Computer Assisted Learning, no. 30, vol. 4, pp. 377 395. 2014. https://doi.org/10.1111/jcal.12057

[57] Chuang, T., Zhi-Feng Liu, E. \& Shiu, W. "Game-based creativity assessment system: the application of fuzzy theory". Multimed Tools Appl 74, 9141-9155, 2015. https://doi.org/10.1007/s11042-014-2070. 